\title{
COMPANY FINANCIAL HEALTH: FINANCIAL STATEMENT USERS' AND COMPILERS' PERCEPTIONS
}

\author{
Elda du Toit* \\ University of Pretoria
}

Elda.dutoit@up.ac.za.

Received: September 2013

\author{
Frans Vermaak" \\ University of Pretoria \\ Frans.vermaak@up.ac.za.
}

Accepted: May 2014

\begin{abstract}
Some prior studies have investigated using analyses of financial statements to reveal companies' financial health, but the usefulness of using such analyses to reveal the financial health of companies and possible presence of accounting irregularities in South African companies needed further investigation. This study examines whether users and compilers of financial statements believe that analysing financial statements can provide clear indications of companies' financial health. The study was conducted by means of a structured questionnaire based on statements made by experts in the field of accounting and financial statement analysis. The results from 237 respondents show that the compilers and users of financial statements are convinced of the usefulness of financial statement analysis in evaluations of companies' financial health. This suggests that close scrutiny of a company's financial statements, with an attitude of scepticism, has the potential to reveal possible irregularities and raise red flags about unhealthy company practices.
\end{abstract}

Keywords

Accounting irregularities; decision-making; decision-usefulness; financial health; financial statements; prediction; ratio analysis

* Dr $\boldsymbol{\varepsilon}$ du Toit is a lecturer in the Department of Financial Management, University of Pretoria, South Africa.

\#Prof FNS Vermaak is an associate professor in the Department of Financial Management, University of Pretoria, South Africa. 


\section{INTRODUCTION}

The financial statements of a company should hold the potential to reveal the presence of accounting irregularities if one is able to observe the right company characteristics (Du Toit, 2008). Such characteristics may reveal the presence of accounting irregularities that, in turn, affect the financial health of a company and the trustworthiness of its financial statements.

One way to answer the question of whether or not financial statements can be regarded as useful by users and compilers of these financial statements in assessing the financial health of a company is to ask the users and compilers of financial statements some questions on their experiences. Hence, in this study, a survey questionnaire was used, structuring questions to provide answers in respect of three particular constructs relating to the usefulness of financial statements to reveal companies' financial health.

The results of the survey reveal that the compilers and the users of financial statements agree on the usefulness of financial statements and financial ratio analysis of a company for decision-making. However, they also indicated that the financial statements alone may not be sufficient and that other sources also need to be consulted.

\section{RESEARCH PROBLEM}

A number of prior studies have investigated the use of financial statement analysis to reveal the financial health of a company. The most prominent amongst these were Apostolou, Hassell and Webber (2001), Baucus and Near (1991), Beasley (1996), Beasley, Carcello and Hermanson (2001), Beasley, Carcello, Hermanson and Lapides (2000) Bell and Carcello (2000) Beneish (1997), Calderon and Green (1994), Cressey (1986), Dechow, Sloan and Sweeney (1996), DeFond and Jiambalvo (1991), Gerety and Lehn (1997), Kinney and McDaniel (1989), Mitchell (1997), Robertson (2002), Saksena (2001), Summers and Sweeney (1998), Tipgos (2002) and Wells $(1990,1997,2001)$. However, the use of financial analysis to reveal companies' financial health and the possibility of accounting irregularities in South African companies, specifically for interested parties such as creditors and investors who may not have access to internal company information, requires further investigation. Du Toit (2012) indicated that most of the literature originates from the USA, with very little research done in South Africa.

Hence, the current study explored the research proposition that using financial statement analysis has the potential to give a clear indication of the financial health of a company. For purposes of this study, "financial health" is defined as the state of a company in terms of the truthfulness, trustworthiness and transparency of its accounting data and published financial statements.

The research problem can be broken down into three constructs that were covered in a questionnaire and supported by a factor analysis of the questionnaire results. The questionnaire was designed to elicit the opinions of users and compilers of financial statements on these constructs:

- Construct 1: Financial statements can be used for decision-making and to predict the company's financial future.

- Construct 2: Ratio analysis is useful in analysing a company's financial health. 
- Construct 3: There is a need to use more than financial information from the financial statements when a company's financial health is analysed.

The remainder of the paper consists of a literature review to provide some background on and a context to the research problem, followed by details of the research method and a discussion of the research results.

\section{LITERATURE REVIEW}

The widely published irregularities in companies such as WorldCom, Enron and Parmalat in the international arena, and Macmed, Saambou and Tigon Holdings in South Africa, are indicative of the magnitude of the financial losses and other problems that investors can face if they do not have the ability to interpret possible indicators of mismanagement and pressure being put on the financial health of the company. Both individuals and groups constantly develop new and ingenious ways to deceive customers, investors, the government and others. It therefore becomes increasingly important to have the ability to measure the financial health of a company (Du Toit, 2012).

There is growing awareness that stakeholders need to devise ways to use financial statement analysis better to protect their interests by identifying problem areas early. According to Cressey (1986:195), there is a widespread belief that accounting irregularities will decline in frequency and severity if more people know more about them, and if that knowledge is used to prevent such abuses. This is important not only for stakeholders, but also for those inside the organisation. Hussain, Kennedy and Kierstead (2010:72) claim that employees need to be educated so that they can better understand accounting irregularities, the internal controls and their role in the companies they work in. They argue that companies should not only rely on a yearly audit to detect accounting irregularities.

It is imperative that more people know how to analyse the financial statements and know which company characteristics to look out for in order to evaluate the company's financial health and to detect and identify accounting irregularities. The problem of a lack of education on how to do financial analysis to detect and identify accounting irregularities was also identified by DeZoort, Harrison and Schnee (2012:289), who suggest that tax professionals face increasing pressure to help manage the problem of irregularities, but that tax literature fails to provide clear guidance in this arena.

To detect and identify accounting irregularities which may affect financial health, a good starting point is to have some knowledge about how deliberate accounting irregularities are generally perpetrated. Below, a broad overview is given of the types of methods that are used to perpetrate accounting irregularities which can destroy the financial health of a company. This also explains how the presence of irregularities may manifest in financial statements.

Nieschwietz, Schultz and Zimbelman (2000:204) categorise the types of most prevalent acts of accounting irregularity in order of severity as Type 1: asset overstatement; Type 2: events not recorded; Type 3: revenue overstated; Type 4: specious accounting judgements; Type 5: expenses recorded incorrectly and Type 6: omitted or misleading disclosures. The obvious first place to evaluate financial health and to detect and identify possible accounting irregularities is therefore an analysis of the financial statements of a company. 
Financial ratios are useful to indicate areas where the level of an account can be explained by another account (Kinney, 1979:164). Because financial accounting operates on a double-entry basis, manipulation of one account necessarily means that another account also needs to be manipulated. Financial ratios may be easier to understand and evaluate than financial statement figures as presented on the face of financial statements. Fridson and Alvarez (2002:3) claim that financial analysis, particularly ratios, is useful for various purposes and can be used by a range of people. They focus mostly on investment managers, corporate financiers and commercial lenders, but there is no reason why ratios cannot be successfully employed by investors and creditors who want to protect their interests in a company against corporate misconduct.

Annual reports contain both quantitative and qualitative sections. Interpreters of such reports should bear in mind that the qualitative section also contains some useful information that should form part of any analysis. Rosplock (2001:24) recognises that, apart from financial information and ratios, using industry and economic data to determine trends, bankruptcy risk and cash flow risk, the information disclosed in notes, together with the rate of financing and substantial suits, liens or judgements that could affect the company, are also useful. Most of this information is found in the notes that accompany the financial statements, making the information readily available to all interested parties. A similar observation was made by Ames, Brazel, Jones, Rich and Zimbelman (2012:C28), who found that non-financial measures such as the number of employees, square metres of operations, customer satisfaction and the number of customers of a company can be useful to assess the risk of accounting irregularities in a company. They believe that companies that are committing accounting irregularities may find it more difficult to falsify non-financial measures.

Financial analyses have been used and continue to be used extensively to evaluate financial performance and position. Some authors, notably Altman (1968) and Altman and Hotchkiss (2006), use financial analyses to attempt to predict possible bankruptcy risk. It falls beyond the scope of this study to explore the extent to which financial analysis can predict financial distress, but a financial analysis that may also able to assist in evaluating overall financial health may be helpful in detecting and identifying accounting irregularities that can manifest in the financial statements.

Wells (1997:475) acknowledges the importance of analysing the financial statements and recommends using almost all the financial ratios to evaluate financial health and to investigate accounting irregularities. He specifically refers to the liquidity, activity, leverage and profitability ratios, which he considers useful ratios to evaluate the relationship between particular financial statement line items. Schilit (1993:125) suggests that an analysis of the quality of earnings of a company is useful in determining its risk of succumbing to accounting irregularities and damaging financial health. Earnings tend to be one of the first places where manipulation occurs.

Another measure for financial health analyses as recommended by Schilit (1993:133) is the relationship between sales and inventory on the one hand, and that between sales and accounts receivable on the other. Normally, a company anticipates its future sales and then orders inventory accordingly. Sudden growth in inventory without a corresponding growth in sales may therefore be a sign of trouble. Moreover, if the accounts receivable balance grows faster than sales, this may indicate misrepresented sales. The empirical research of the study indicates that the users and compilers of financial statements agree on the use of financial statements and the ratios that can be derived from this in analysing financial health. 


\section{RESEARCH METHOD}

\subsection{The research instrument}

A questionnaire was distributed to 500 users and compilers of financial statements in the South African business environment (the sample is discussed below). A user of financial statements is considered to be a person who uses the published financial statements of a company for investment decisions, whether for his/her own use or for clients. A compiler prepares financial statements for one or more companies. If a person is listed as both a compiler and a user, it means that he/she compiles financial statement for a company and also uses financial statements of other companies for personal investment decisions. This implies that there is no bias on the part of the person using the financial statements, also being the compiler.

The questionnaires were analysed statistically to arrive at a conclusion regarding the experiences of practitioners who compile and/or use financial statements and their opinions regarding the use of financial statements and accounting data to analyse the financial health of a company. Before any effort can be made to educate interested parties about the use of financial analysis to evaluate financial health, there has to be some clarity on the views of those parties that currently use and compile financial statements - this is what the questionnaire aimed to investigate.

The questionnaire contains 25 statements. Respondents had to indicate on a five-point Likert scale whether they strongly agree, agree, are undecided, disagree or strongly disagree with these statements. Likert scale questionnaires provide a measurement method based on standard response categories (Babbie \& Mouton, 2007). A Likert scale is a tool for researchers to measure the perceptions of respondents on a variety of topics in a structured way. It also makes it possible to compare respondents' feedback. Likert scales are perceived as ideal for the social sciences, because the result is based on empirical data derived from the respondents' answers rather than subjective opinions held by the researchers (Babbie \& Mouton, 2007). The homogeneous scales that respondents have to use for their answers also increase the probability of a unitary attitude (Khomba, 2011). It follows that the Likert scale is the best method of research for the study reported on here.

The statements in the questionnaire that the respondents were asked to rate on the Likert scale were both positive and negative and randomly placed in the questionnaire in order to encourage respondents to think about their answers. The individual results on each of the statements were analysed using descriptive statistics by simply counting the number of respondents that gave a particular response to a given statement. A score was calculated by assigning a numerical value to each response, from a 1 for 'strongly disagree' to a 5 for 'strongly agree'. The results of the questionnaire were statistically analysed using the BMDP Statistical Software Package ${ }^{\odot}$ and $\mathrm{IBM}^{\circledast} \mathrm{SPSS}^{\oplus} 21$. Underlying relationships between statements were determined by means of a factor analysis.

The objective of using questionnaires was to obtain information from the users and the compilers of financial statements. The aim was not to develop a new theory, but rather to test and verify conclusions that were already reached, to supplement and verify the results of the prior research. Using questionnaires can lead to the discovery of a more in-depth understanding of the perceptions and experiences of those individuals affected by the information contained in financial statements. It enables a researcher to capture information on how the targeted respondents, as representatives of the population, interpret and experience their environment. $A$ 
structured questionnaire format was chosen, because it allows all the respondents to react to the same set of statements. Open-ended questions were avoided, because in such a question the respondent gives his/her own observation and it is more difficult to analyse statistically. Making use of a structured questionnaire gives a researcher the added benefit of reaching a wider variety of respondents over a larger geographical region than would be possible if personal interviews were conducted and personal observations had to be made. The confidentiality that this type of survey provides to respondents also tends to increase the response rate (Khomba, 2011).

\subsection{Development of the questionnaire}

To develop the questionnaire, the researchers started with statements by experts about accounting and the use (s) of financial analysis. Based on these, new statements were written to test respondents' opinions on the specific topic. The researchers decided not to use the experts' statements as they stood, to avoid possible bias from the respondent. In the analysis of the survey results, the statements are linked again to the statements of the experts. This procedure resulted in 25 statements on accounting and financial statement analysis. Khomba (2011) observes that the shorter and more concise the statements and the entire questionnaire, the better the results.

After developing the initial questionnaire, it was presented to a sample of six (6) respondents in a pilot study. The link to the online survey was emailed to six people known to the researcher and who have basic financial knowledge. In the email the preliminary respondents were requested to give their opinion on the statements in the questionnaire and also to provide feedback on how they interpreted the statements. This procedure was followed to eliminate any potential misunderstanding of the statements and to prevent possible problems which could lead to unreliable results and statistics. The responses from the pilot study allowed the researchers to refine the questionnaire and correct all the deficiencies identified by the respondents to the pilot study.

The final questionnaire consisted of two sections. Section A only required a respondent to state whether he/she is a compiler and/or a user of financial statements. For the purposes of this study, no further demographic information was necessary. Section B presented the 25 statements in an uncategorised table. Even though the statements could be divided into separate sections for accounting and financial analysis (or 'ratios'), and between positive, negative and neutral, it was not presented in that way to the respondent. This decision was made to avoid any possible bias from the respondent.

To make completion and collection of results easier, the questionnaire was prepared in an electronic format, using Qualtrics Online Survey Software®.

\subsection{Sampling design and sampling method}

Sampling is necessary in order to achieve representativeness, with the targeted respondents being representative of the population from which they come. In order to achieve representativeness, judgemental sampling was performed, where the appropriate groups to be targeted were selected first. The main consideration was that every respondent must be a compiler and/or a user of financial statements in South Africa. The questionnaire was thus sent to people with accounting and financial knowledge in the South African business environment. From the 237 useful responses that were obtained, 76 (31\%) were only compilers of financial 
statements, 35 (14\%) were only users and the majority of 126 (52\%) were both compilers and users of financial statements.

The researchers aimed to have a minimum of 200 respondents. Since the average response rate from similar studies is approximately $45 \%$ (Khomba, 2011), the sample size was determined as follows:

$$
\text { Sample size }=\frac{\text { Targeted number of respondents }}{\text { Expected response rate }}=\frac{200}{0.45}=\text { (at least) } 444 \text { respondents }
$$

A volunteer sampling approach was followed in the distribution of the questionnaire. The questionnaire was sent out via email in electronic format to 500 potential respondents in the South African business environment. The survey had settings that make it possible to 'lock' the questionnaire so that it could only be completed by those respondents who had been invited to do so by the researcher. This ensured the integrity of the questionnaire results by excluding unwanted access.

\subsection{Analysis of the results}

The descriptive statistics with which the analysis commences consist of the mean, median and mode. These are all three measures of the 'centredness' of the responses. The aim was to establish the overall tendency of the answers of the respondents.

Factor analysis was also performed on the results obtained from the questionnaire. This can be described as bivariate analysis, since it looked at correlations between different statements to determine whether there were any relations between the statements. The most common type of factor analysis, namely exploratory factor analysis, was used in this study to uncover latent dimensions in the set of statements of the questionnaire. This allowed the reduction of a large number of items into smaller, more manageable factors.

\section{STATISTICAL ANALYSIS OF THE PUESTIONNAIRE}

From the 500 questionnaires that were sent out, a total of 244 respondents gave feedback. Seven of the completed questionnaires were eliminated because they were incomplete. This resulted in a satisfactory response rate of 237 out of 500 (47\%).

The figures that are used to describe the mean, the standard deviation and the median are based on a number allocated to each response that can possibly be given by a respondent. The numbers were allocated as 1 = 'Strongly agree'; 2 = 'Agree'; 3 = 'Neither agree nor disagree'; 4 = 'Disagree'; 5 = 'Strongly disagree'.

\subsection{Basic descriptive analysis}

The basic descriptive analysis indicates that most of the respondents agreed with positive statements about the use of financial statement information for decision-making and evaluating the financial health of an organisation. This can be observed from the number of statements for which the mean, median and mode had a value of 2 (21 out of 25 statements or $84 \%)$.

Two statements had a mean, median and mode closer to 4 , or 4 exactly. Those statements 
created a negative picture about the use of financial statement information for evaluating financial health (Statements 12 and 14). Two other statements that raised some concern about the usefulness of financial statement information for evaluating financial health were Statements 7 and 21 . These received a neutral response, with a mean, median and mode with a value of 3 .

From the results summarised per statement in TABLE 1 , it can be concluded that the financial statements are mostly perceived to be useful in evaluating the financial health of a company.

\section{TABLE 1: Basic descriptive statistics per statement}

\begin{tabular}{|c|c|c|c|c|}
\hline No & Statement & Mean & Median & Mode \\
\hline 1 & $\begin{array}{l}\text { Accounting data in the annual report has the power to predict } \\
\text { problems with financial health. }(\mathrm{S} 1)\end{array}$ & 1.95 & 2.00 & 2 \\
\hline 2 & $\begin{array}{l}\text { The annual report can help one to make financial decisions } \\
\text { about a company. (S2) }\end{array}$ & 1.82 & 2.00 & 2 \\
\hline 3 & $\begin{array}{l}\text { Information in the annual report is not enough to make } \\
\text { deductions about the financial health of a company. (s3) }\end{array}$ & 2.61 & 2.00 & 2 \\
\hline 4 & $\begin{array}{l}\text { It can happen that false information appears in the annual } \\
\text { report. (S4) }\end{array}$ & 1.95 & 2.00 & 2 \\
\hline 5 & $\begin{array}{l}\text { It is important to consider interactions between financial } \\
\text { statement items when evaluating a company. (S5) }\end{array}$ & 1.62 & 2.00 & 2 \\
\hline 6 & $\begin{array}{l}\text { It is the purpose of financial statements to provide } \\
\text { information to make decisions about the financial health of a } \\
\text { company possible. (S6) }\end{array}$ & 2.03 & 2.00 & 2 \\
\hline 7 & $\begin{array}{l}\text { Models (e.g. the Altman model for financial distress) used to } \\
\text { measure financial health cannot be trusted to give a perfect } \\
\text { view of the state of a company. (S7) }\end{array}$ & 2.64 & 3.00 & 3 \\
\hline 8 & $\begin{array}{l}\text { More than only numbers needs to be considered when one } \\
\text { analyses the annual report to determine financial health. (S8) }\end{array}$ & 1.70 & 2.00 & 2 \\
\hline 9 & $\begin{array}{l}\text { I am willing to make decisions about a company based on } \\
\text { historical information. ( } \mathrm{S} 9 \text { ) }\end{array}$ & 2.79 & 2.00 & 2 \\
\hline 10 & $\begin{array}{l}\text { Predicting the future is one of the objectives of annual } \\
\text { reports. ( }(\mathrm{D} 10)\end{array}$ & 2.98 & 3.00 & 2 \\
\hline 11 & $\begin{array}{l}\text { Qualitative information in the annual report is generally } \\
\text { viewed as being of lesser importance. (S1l). }\end{array}$ & 3.01 & 3.00 & 2 \\
\hline 12 & Ratio analysis as a tool ought to be eliminated. (S12)* & 4.06 & 4.00 & 4 \\
\hline 13 & $\begin{array}{l}\text { Ratio analysis can serve a number of purposes and can even be } \\
\text { used to indicate problems with financial health. (S13) }\end{array}$ & 1.83 & 2.00 & 2 \\
\hline 14 & $\begin{array}{l}\text { Ratios are not as effective as some other measures of } \\
\text { analysis. (S14)* }\end{array}$ & 3.27 & 3.00 & 4 \\
\hline
\end{tabular}




\begin{tabular}{|c|c|c|c|c|}
\hline No & Statement & Mean & Median & Mode \\
\hline 15 & $\begin{array}{l}\text { Ratios can be useful, but it depends on the selection of ratios. } \\
\text { (S15) }\end{array}$ & 1.89 & 2.00 & 2 \\
\hline 16 & $\begin{array}{l}\text { So-called 'fraud' allegations can cause enough damage to a } \\
\text { company so that it fails. (S16) }\end{array}$ & 2.21 & 2.00 & 2 \\
\hline 17 & $\begin{array}{l}\text { The analyses of the financial statements in the annual report } \\
\text { by means of ratios can be used to detect financial health } \\
\text { problems. ( } S 17 \text { ) }\end{array}$ & 2.01 & 2.00 & 2 \\
\hline 18 & $\begin{array}{l}\text { The information from financial statements can be used for } \\
\text { decision-making. ( } \mathrm{S} 18 \text { ) }\end{array}$ & 1.91 & 2.00 & 2 \\
\hline 19 & $\begin{array}{l}\text { The information in the annual report can be used for predictive } \\
\text { purposes. (S19) }\end{array}$ & 2.33 & 2.00 & 2 \\
\hline 20 & $\begin{array}{l}\text { The information in the financial statements as contained in } \\
\text { the annual report is not enough to base decisions on. (S20) }\end{array}$ & 2.69 & 2.00 & 2 \\
\hline 21 & $\begin{array}{l}\text { The narrative parts of the annual report may be of more value } \\
\text { than the numeric parts. (S21) }\end{array}$ & 2.77 & 3.00 & 3 \\
\hline 22 & $\begin{array}{l}\text { There are measures other than the annual report that can be } \\
\text { used to indicate the financial health of a company. ( } 522 \text { ) }\end{array}$ & 2.19 & 2.00 & 2 \\
\hline 23 & $\begin{array}{l}\text { There are other sources of information that need to be } \\
\text { consulted when analysing a company's financial health. ( } 523 \text { ) }\end{array}$ & 1.84 & 2.00 & 2 \\
\hline 24 & $\begin{array}{l}\text { There are various means to manipulate the financial } \\
\text { statements. (S24) }\end{array}$ & 1.97 & 2.00 & 2 \\
\hline 25 & $\begin{array}{l}\text { There is a relationship between the fairness of presentation in } \\
\text { the annual report and a company having financial difficulties. } \\
\text { (S25) }\end{array}$ & 2.45 & 2.00 & 2 \\
\hline
\end{tabular}

Source: SPSS Output

* Statements that are given in negative form.

\subsection{Factor analysis}

Factor analysis attempts to identify underlying variables (or factors) that explain a pattern of correlations within a set of observed variables. The main applications of factor analysis techniques are, first, to reduce the number of variables, and, second, to detect any potential structure in the relationships between variables ( $(\varepsilon l s, 2007)$. Therefore, factor analysis was applied in this study as a data reduction or structure detection method.

Three constructs for the questionnaire survey were described as part of the research problem, namely that financial statements can be used for decision-making and to predict the company's financial future (Construct 1 ), that ratio analysis is useful in analysing a company's financial health (Construct 2), and that there is a need to use more than financial information from the financial statements when a company's financial health is analysed (Construct 3 ). The questionnaire was developed to address these constructs. 
If factor analysis results in factors similar to the initial constructs the validity of the constructs are proven. The factor analysis was performed on the data, using Oblique Rotation and then the Direct Oblimin method. The results from the factor analysis are described in the sections that follow.

A first and second factor analysis performed in BDMP(C indicated which statements had no relation to the three factors. Five were identified and these were disregarded for the rest of the factor analysis. The statements that were discarded for the purposes of the factor analysis were Statements 1, 5, 7, 11 and 16. That left 20 statements from which the three initial constructs could be proven or disproven. TABLE 2 shows the eigenvalues drawn from the factor analysis. As the questionnaire was developed to collect information on three constructs, the top three eigenvalues are thus the factors related to the initial constructs

TABLE 2: Histogram of eigenvalues of unaltered correlation matrix

\begin{tabular}{|c|c|}
\hline Ranking & Eigenvalue \\
\hline 1 & 3.31621 \\
\hline 2 & 2.49176 \\
\hline 3 & 1.91032 \\
\hline 4 & 1.40414 \\
\hline 5 & 1.14668 \\
\hline 6 & 1.07497 \\
\hline 7 & 0.97955 \\
\hline 8 & 0.95047 \\
\hline 9 & 0.86084 \\
\hline 10 & 0.78508 \\
\hline 11 & 0.73873 \\
\hline 12 & 0.66861 \\
\hline 13 & 0.61856 \\
\hline 14 & 0.56639 \\
\hline 15 & 0.52520 \\
\hline 16 & 0.48938 \\
\hline 17 & 0.44720 \\
\hline 18 & 0.38475 \\
\hline 19 & 0.33990 \\
\hline 20 & 0.30127 \\
\hline
\end{tabular}

Source: SPSS Output 
To test the internal reliability of the factor analyses, a Cronbach's Alpha $(\alpha)$ was calculated for each of the three factors as identified by the top three eigenvalues (refer to TABLE 3).

TABLE 3: Cronbach coefficient alpha for the three identified factors

\begin{tabular}{|c|c|c|}
\hline Factor & Variables & Alpha \\
\hline \multirow{2}{*}{ Factor 1} & Raw & 0.692084 \\
\hline & Standardised & 0.708519 \\
\hline \multirow{2}{*}{ Factor 2} & Raw & 0.702871 \\
\hline & Standardised & 0.719509 \\
\hline \multirow{2}{*}{ Factor 3} & Raw & 0.570900 \\
\hline & Standardised & 0.594185 \\
\hline
\end{tabular}

Source: SPSS Output

TABLE 4 indicates how Cronbach's Alpha can be interpreted. Even though the Cronbach Alpha value for Factor 3 was low, a decision was made to include it in the analysis, since the factor does correlate with a possible factor that was initially identified.

TABLE 4: Rule of thumb in interpreting Cronbach's Alpha

\begin{tabular}{cc} 
Cronbach's alpha & Internal consistency \\
\hline$\alpha \geq 0.9$ & Excellent \\
$0.8 \leq \alpha<0.9$ & Good \\
$0.7 \leq \alpha<0.8$ & Acceptable \\
$0.6 \leq \alpha<0.7$ & Puestionable \\
$0.5 \leq \alpha<0.6$ & Poor \\
$\alpha<0.5$ & Unacceptable \\
\hline
\end{tabular}

Source: SPSS Output

The sections that follow describe the factors/constructs in detail.

\subsubsection{Analysis of Factor 1}

Factor 1 can be described as being concerned with the decision-making and predictiongenerating power of financial statements. The items identified as relating to Factor 1 were Statements 2, 3, 6, 9, 10, 18, 19 and 20. 


\subsubsection{Analysis of Factor 2}

Factor 2 can be described as being concerned with the use of ratios when a company's financial health is analysed. The items identified as relating to Factor 2 were Statements 12, 13, 14 and 17.

\subsubsection{Analysis of Factor 3}

Factor 3 can be described as being concerned with whether other sources of information need to be consulted when the financial health of a company is evaluated. The items identified as relating to Factor 3 were Statements 4, 8, 15, 21, 22, 23, 24 and 25.

\subsubsection{Factor scores and interpretation}

Factor 1 proves the validity of Construct 1 . By virtue of the results of the questionnaire, it can be seen that the users and compilers of financial statements agree that financial statements are useful in decision-making and predicting a company's future.

Factor 2 proves the validity of Construct 2. The results of the questionnaire indicate that the users and compilers of financial statements agree that ratios are useful in deducing the financial health of a company from the financial statements.

Factor 3 proves the validity of Construct 3 . From the questionnaire results it is clear that the users and compilers of financial statements agree that additional information, over and above that contained in the financial statements, needs to be used when the financial health of a company is evaluated.

\section{DISCUSSION AND CONCLUSION}

The results from the questionnaire show that the users and compilers of financial statements tend to trust the information contained in the financial statements to analyse the financial health of a company.

Three constructs were initially identified and formed the basis of three constructs (or factors) on which the study rested. The outcome of the results was as follows:

- financial statements are useful for decision-making and prediction purposes;

- ratio analysis (interactions between financial statement items) can be useful when analysing a company's financial health; and

- information other than only financial information from the financial statements needs to be considered when a company's financial health is analysed.

The research problem has thus been answered in that there is evidence of a clear perception among users and compilers of financial statements of definite potential in the use of financial statement analysis to give an indication of the financial health of a company. 


\section{RECOMMENDATIONS}

The results of this study indicate that users and compilers of financial statements believe that financial statements can be used to reveal information about a company's financial health. An attitude of scepticism and close scrutiny of the financial statements can therefore assist in revealing more about a company's activities than the management of a company may anticipate.

Interested parties should take note of the additional benefits attached to analysing an annual report bearing possible accounting irregularities in mind. It ensures that the reader pays attention to a range of different quantitative and qualitative items that may be overlooked under normal circumstances. An analysis of the annual report with the goal of detecting and identifying anything that may signify accounting irregularities or the risk that they may be perpetrated can potentially reveal other problems as well, such as financial distress.

\section{LIST OF REFERENCES}

Altman, E.I. \& Hotchkiss, દ. (2006). Corporate Financial Distress and Bankruptcy: Predict and Avoid Bankruptcy, Analyse and Invest in Distressed Debt, $3^{\text {rd }}$ edition. Hoboken, NJ: Wiley.

Altman, E.I. (1968). Financial ratios, discriminant analysis and the prediction of corporate bankruptcy. Journal of Finance, 23(4), pp. 589-609.

Altman, E.I. (1983). Corporate Financial Distress: A complete guide to predicting, avoiding, and dealing with bankruptcy. New York: Wiley-Interscience.

Altman, E.I. \& Hotchkiss, દ. (2006). Corporate financial distress and bankruptcy: Predict and avoid bankruptcy, analyse and invest in distressed debt. New Jersey: John Wiley and Sons.

Ames, D., Brazel, J.F., Jones, K.L., Rich, J.S. \& Zimbelman, M.F. (2012). Using nonfinancial measures to improve fraud risk assessments. Current Issues in Auditing, 6(1), pp. C28-C34.

Anderson, R.H. \& Epstein, M.J. (1996). The usefulness of corporate annual reports to shareholders in Australia, New Zealand and the United States: an international comparison. Studies in Managerial Accounting, Vol. 4. Connecticut: JAl Press.

Apostolou, B. Hassell, J.M. \& Webber, S.A. (2001). Management fraud risk factors: ratings by forensic experts. CPA Journal, $71(10)$, pp. 48-52.

Babbie, E. \& Mouton, J. (2007). The Practice of Social Research. Cape Town: Oxford University Press Southern Africa.

Baucus, M.S. \& Near, J.P. (1991). Can illegal corporate behaviour be predicted? An event history analysis. Academy of Management Journal, 34(1), pp. 9-36.

Beasley, M.S. (1996). An empirical analysis of the relation between the board of director composition and financial statement fraud. Accounting Review, 71(4), pp. 443-465.

Beasley, M.S. Carcello, J.V. \& Hermanson, D.R. (2001). Financial reporting fraud: could it happen to you? Journal of Corporate Accounting and Finance, 12(4), pp.3-9. 
Beasley, M.S. Carcello, J.V. Hermanson, D.R. \& Lapides, P.D. (2000). Fraudulent financial reporting: consideration of industry traits and corporate governance measures. Accounting Horizons, 14(4), pp. 441-454.

Bell, T.B. \& Carcello, J.V. (2000). A decision aid for assessing the likelihood of fraudulent financial reporting. Auditing, 19(1), pp. 169-184.

Beneish, M.D. (1997). Detecting GAAP violation: implications for assessing earnings management among firms with extreme financial performance. Journal of Accounting and Public Policy, 16, pp. 271-309.

Brigham, E.F. Gapenski, L.C. \& Daves, P.R. (1999). Intermediate financial management, $6^{\text {th }}$ edition. New York: Harcourt Brace College Publishers.

Calderon, T.G. \& Green, B.P. (1994). Signalling fraud by using analytical procedures. Ohio CPA Journal, 53(2), pp. 27-38.

Cressey, D.R. (1986). Why managers commit fraud. Australian and New Zealand Journal of Criminology, 19(4), pp. 195-209.

Dechow, P.M. Sloan, R.G. \& Sweeney, A.P. (1996). Causes and consequences of earnings manipulations: an analysis of firms subject to enforcement actions by the SEC. Contemporary Accounting Research, 13(1), pp. 1-36.

DeFond, M.L. \& Jiambalvo, J. (1991). Incidence and circumstances of accounting errors. Accounting Review, 66(3), pp. 643-655.

DeZoort, F.T., Harrison, P.D. \& Schnee, E.J. (2012). Tax professionals' responsibility for fraud detection: the effects of engagement type and audit status. Accounting Horizons, 26(2), pp. 289306.

Du Toit, $\varepsilon$. (2008). Characteristics of companies with higher risk of financial statement fraud: a literature survey. South African Journal of Accounting Research, 22(1), pp. 19-44.

Els, G. (2007). Utilising continued professional development of ethics amongst prospective chartered accountants. Unpublished doctoral thesis. University of Johannesburg, Johannesburg, Gauteng Province, South Africa.

Epstein, M.J. \& Pava, M.L. (1993). The Shareholders' Use of Corporate Annual Reports. Connecticut: JAI Press.

Fridson, M \& Alvarez, F. (2002). Financial Statement Analysis: A Practitioner's Guide. $3^{\text {rd }}$ Edition. New York, Ny: Wiley.

Gerety, M. \& Lehn, K. (1997). The causes and consequences of accounting fraud. Managerial and Decision Economics (1986-1998), 18(7/8), pp. 587-599.

Goldberg, L. (2001). A journey into accounting thought. London: Routledge-Taylor and Francis.

Gouws, D.G. \& Lucouw, P. (1999). The process beyond the numbers and ratios. Meditari Accountancy Research, 7, pp. 99-121.

Hirshleifer, D. \& Teoh, S.H. (2003). Limited attention, information disclosure and annual reporting. Journal of Accounting and Economics, 36, pp. 337-386.

Hussain, M.M., Kennedy, P. \& Kierstead, V. (2010). Can audit prevent fraudulent financial reporting practices? Study of some motivational factors in two Atlantic Canadian entities. Issues in Social and Environmental Accounting, 4(1), pp. 65-73 
Khomba, J.K. (2011). Redesigning the balanced scorecard model: an African perspective. Unpublished doctoral thesis. Pretoria: University of Pretoria.

Kinney, W.R. (1979). The predictive power of limited information in preliminary analytical review: an empirical study. Journal of Accounting Research, 17(Supplement), pp. 148-165.

Kinney, W.R. \& McDaniel, L.S. (1989). Characteristics of firms correcting previously reported quarterly earnings. Journal of Accounting and Economics, February, pp. 71-94.

Mitchell, S.H. (1997). Management fraud trends. The Secured Lender New York, 53(6), pp. 104-108.

Nieschwietz, R.J., Schultz Jr, J.J. \& Zimbelman, M.F. (2000). Empirical research on external auditors' detection of financial statement fraud. Journal of Accounting Literature, 19, pp. 190-246.

Prigogine, I. \& Stengers, I. (1984). Order out of chaos: man's new dialogue with nature. Bantam, New York.

Qua-Enoo, G.A. (2002). Do readers of annual reports really understand them? Non-refereed financial accounting paper presented at the SAAA conference held in Port Elizabeth, South Africa $26-28$ June 2002.

Robertson, J.C. (2002). Fraud examination for managers and auditors, $4^{\text {th }}$ edition. Austin, TS: Viesca. Rosplock, M. (2001). Advanced forensic analysis: Part Two. The White Paper, 15(6), pp. 23-25.

Saksena, P. (2001). The relationship between environmental factors and management fraud: an empirical analysis. International Journal of Commerce and Management: Indiana, 11(1), pp. 120-139.

Schilit, H.M. (1993). Financial Shenanigans: How to Detect Accounting Gimmicks and Fraud in Financial Reports. New York, NY: McGraw-Hill

Summers, S.L. \& Sweeney, J.T. (1998). Fraudulently misstated financial statements and insider trading: an empirical analysis. Accounting Review, 73(1), pp. 131-146.

Tipgos, M.A. (2002). Why management fraud is unstoppable. CPA Journal: 72(12), pp. 34-41.

Wells, J.T. (1990). Six common myths about fraud. Journal of Accountancy, 169(2), pp. 82-88.

Wells, J.T. (1997). Occupational fraud and abuse. Austin, TS: Obsidian.

Wells, J.T. (1997). Occupational Fraud and Abuse. Austin, TX: Obsidian.

Wells, J.T. (2001). And nothing but the truth: uncovering fraudulent disclosures. Journal of Accountancy, 192(1), pp. 47-52.

Wells, W.H. (2004). A beginner's guide to event studies. Journal of Insurance Regulation, 22(4), pp. $61-70$.

Wheatley, M.J. (1999). Leadership and the new science. San Francisco: Berret Koehler. 


\section{APPENDIX: The statements of experts on which the questionnaire was based}

\begin{tabular}{|c|c|c|c|}
\hline No & Questionnaire statement & Original statement & Category \\
\hline S1 & $\begin{array}{l}\text { Accounting data has the power to } \\
\text { predict problems with financial } \\
\text { health. }\end{array}$ & $\begin{array}{l}\text { Brigham, Gapenski and Daves (1999) - The } \\
\text { information contained in an annual report is } \\
\text { used by investors to help form expectations } \\
\text { about future earnings and dividends. }\end{array}$ & Accounting \\
\hline S2 & $\begin{array}{l}\text { The annual report can help one to } \\
\text { make financial decisions about a } \\
\text { company. }\end{array}$ & $\begin{array}{l}\text { Altman (1983) - A basic objective of financial } \\
\text { statements is to provide information useful } \\
\text { for making economic decisions. }\end{array}$ & Accounting \\
\hline S3 & $\begin{array}{l}\text { Information in the financial } \\
\text { statements is not enough to make } \\
\text { deductions about the financial } \\
\text { health of a company. }\end{array}$ & $\begin{array}{l}\text { Anderson and Epstein (1996) - Research has } \\
\text { shown that the annual report does not } \\
\text { provide enough information. }\end{array}$ & Accounting \\
\hline S4 & $\begin{array}{l}\text { It can happen that false } \\
\text { information appears in the annual } \\
\text { report. }\end{array}$ & $\begin{array}{l}\text { Wheatley (1999) - Information is so vital to } \\
\text { the continued existence of an organisation } \\
\text { that people tend to fill gaps by making up } \\
\text { information }\end{array}$ & Accounting \\
\hline S5 & $\begin{array}{l}\text { It is important to consider } \\
\text { interactions between financial } \\
\text { statement items when evaluating } \\
\text { a company. }\end{array}$ & $\begin{array}{l}\text { Prigogine and Stengers (1984) - In general, } \\
\text { interactions cannot be ignored. }\end{array}$ & Accounting \\
\hline S6 & $\begin{array}{l}\text { It is the purpose of financial } \\
\text { statements to provide information } \\
\text { to make decisions about the } \\
\text { financial health of a company } \\
\text { possible. }\end{array}$ & $\begin{array}{l}\text { Epstein and Pava (1993) - One of the main } \\
\text { purposes of the annual report is to provide } \\
\text { parties with an interest in a company with } \\
\text { information about that company. }\end{array}$ & Accounting \\
\hline S7 & $\begin{array}{l}\text { Models (e.g. the Altman model for } \\
\text { financial distress) used to } \\
\text { measure financial health cannot } \\
\text { be trusted to give a perfect view } \\
\text { of the state of a company. }\end{array}$ & $\begin{array}{l}\text { Altman and Hotchkiss (2006) - In the Enron } \\
\text { and WorldCom cases, and several other fraud } \\
\text { cases that we are aware of, although tools } \\
\text { like Z-score and EDF (expected default } \\
\text { frequency) were available, losses were still } \\
\text { incurred by even the most sophisticated } \\
\text { investors and financial institutions. Having } \\
\text { the models is simply not enough! }\end{array}$ & Ratios \\
\hline
\end{tabular}

More than the numbers need to be considered when analysing the financial statements to determine financial health.

I am willing to make decisions

S9 about a company based on historical information.

Predicting the future is one of the objectives of financial statements.
Goldberg (2001) - The interpreter and user of annual reports need to take a look at the underlying concepts that the data is based on. Nothing should therefore be left out, as it Accounting can have an influence on how other aspects ought to be interpreted.

Qua-Enoo (2002) - Annual reports are simply made available too late to be thoroughly meaningful for decision-making and thus Accounting also prediction.

Epstein and Pava (1993) - In addition to the problem that annual reports are often the only information available to interested Accounting parties, there is the added responsibility on annual reports that they are used to predict 


\begin{tabular}{|c|c|c|c|}
\hline No & Questionnaire statement & Original statement & Category \\
\hline & & $\begin{array}{l}\text { the future. This has even become one of the } \\
\text { objectives of accounting; together with } \\
\text { comparison and evaluation. }\end{array}$ & \\
\hline S11 & $\begin{array}{l}\text { Qualitative information is viewed } \\
\text { as being of lesser importance. }\end{array}$ & $\begin{array}{l}\text { Wheatley (1999) - Too much focus on } \\
\text { quantitative measurement is a major problem } \\
\text { in companies and other organisations. }\end{array}$ & Accounting \\
\hline S12 & $\begin{array}{l}\text { Ratio analysis as a tool ought to } \\
\text { be eliminated. }\end{array}$ & $\begin{array}{l}\text { Altman and Hotchkiss (2006) - Starting in the } \\
1960 \text { s, some practitioners, and certainly } \\
\text { many academicians, had been moving toward } \\
\text { the possible elimination of ratio analysis as } \\
\text { an analytical technique in assessing firm } \\
\text { performance. }\end{array}$ & Ratios \\
\hline S13 & $\begin{array}{l}\text { Ratio analysis can serve a number } \\
\text { of purposes and can even be used } \\
\text { to indicate problems with } \\
\text { financial health. }\end{array}$ & $\begin{array}{l}\text { Beaver (Altman, 1983) claimed that his most } \\
\text { important contribution was to suggest a } \\
\text { framework for the evaluation of accounting } \\
\text { data, not merely for failure prediction, but } \\
\text { for any purpose. }\end{array}$ & Ratios \\
\hline S14 & $\begin{array}{l}\text { Ratios are not as effective as } \\
\text { some other measures of analysis. }\end{array}$ & $\begin{array}{l}\text { Moriarity (Altman, 1983) found that simple } \\
\text { "faces" (multidimensional graphics) were } \\
\text { more effective bankrupt/non-bankrupt } \\
\text { indicators than the ratios. }\end{array}$ & Ratios \\
\hline S15 & $\begin{array}{l}\text { Ratios can be useful, but it } \\
\text { depends on the selection of } \\
\text { ratios. }\end{array}$ & $\begin{array}{l}\text { Edmister (Altman, 1983) concluded that the } \\
\text { predictive power of ratio analysis depends } \\
\text { upon both the choice of analytical method } \\
\text { and the selection of ratios. }\end{array}$ & Ratios \\
\hline S16 & $\begin{array}{l}\text { So-called "fraud" revelations can } \\
\text { cause enough damage to a } \\
\text { company so that it fails. }\end{array}$ & $\begin{array}{l}\text { Altman and Hotchkiss (2006) - But it did go } \\
\text { under, primarily because of the fraud } \\
\text { revelations and the attendant costs due to } \\
\text { the loss of credit availability }\end{array}$ & Accounting \\
\hline S17 & $\begin{array}{l}\text { The analysis of financial } \\
\text { statements by means of ratios can } \\
\text { be used to detect financial health } \\
\text { problems. }\end{array}$ & $\begin{array}{l}\text { Altman and Hotchkiss ( } 2006 \text { ) - The detection } \\
\text { of company operating and financial } \\
\text { difficulties is a subject that has been } \\
\text { particularly amenable to analysis with } \\
\text { financial ratios. }\end{array}$ & Ratios \\
\hline
\end{tabular}

The information from financial

S18 statements can be used for decision-making.

The information in the annual

S19 report can be used for predictive purposes.
Anderson and Epstein (1996) - Accounting can be regarded as one of the information systems in a company, because its main purpose is to provide relevant parties with meaningful information to facilitate decision-making.

Altman (1983) - His (Beaver's) major finding was that financial ratios, or more generally, accounting data, have the ability to predict failure for at least five years before failure.

The information in the financial statements as contained in the annual report is not enough to base decisions on.
Gouws and Lucouw (1999) - A lot of important data is left out when the company is measured and interpreted by means of accounting and the resulting annual reports.
Accounting

Accounting 


\begin{tabular}{|c|c|c|c|}
\hline No & Questionnaire statement & Original statement & Category \\
\hline & & $\begin{array}{l}\text { The final numbers that are provided are only } \\
\text { the proverbial 'tip of the iceberg'. }\end{array}$ & \\
\hline S21 & $\begin{array}{l}\text { The narrative parts of the } \\
\text { financial statements may be of } \\
\text { more value than the numeric } \\
\text { parts. }\end{array}$ & $\begin{array}{l}\text { Qua-Enoo (2002) - More recent research has } \\
\text { indicated that of all the different statements } \\
\text { presented in an annual report, the chairman's } \\
\text { report is deemed the most important. }\end{array}$ & Accounting \\
\hline S22 & $\begin{array}{l}\text { There are measures other than the } \\
\text { annual report that can be used to } \\
\text { indicate the financial health of a } \\
\text { company. }\end{array}$ & $\begin{array}{l}\text { Altman and Hotchkiss (2006) - In general, } \\
\text { ratios measuring profitability, liquidity, } \\
\text { leverage, and solvency, and multidimensional } \\
\text { measures, like earnings and cash flow } \\
\text { coverage, prevailed as the most significant } \\
\text { indicators of financial distress. }\end{array}$ & Ratios \\
\hline S23 & $\begin{array}{l}\text { There are other sources of } \\
\text { information that need to be } \\
\text { consulted when analysing a } \\
\text { company's financial health. }\end{array}$ & $\begin{array}{l}\text { Hirshleifer and Teoh (2003) - Outside factors } \\
\text { that also have an influence on the results in } \\
\text { the annual report, such as the economic } \\
\text { situation and market-related factors, are } \\
\text { normally omitted. }\end{array}$ & Accounting \\
\hline S24 & $\begin{array}{l}\text { There are various means to } \\
\text { manipulate the financial } \\
\text { statements. }\end{array}$ & $\begin{array}{l}\text { DeFond and Jiambalvo (1991) - Both GAAP } \\
\text { alternatives and overstatement errors can be } \\
\text { used to enhance earnings }\end{array}$ & Accounting \\
\hline S25 & $\begin{array}{l}\text { There is a relationship between } \\
\text { the fairness of presentation in the } \\
\text { financial statements and a } \\
\text { company having financial } \\
\text { difficulties. }\end{array}$ & $\begin{array}{l}\text { Altman (1983) - An opinion expressing } \\
\text { doubts concerning a company's ability to } \\
\text { continue as a going concern is based on the } \\
\text { uncertainty of the fairness of presentation of } \\
\text { the financial statements. }\end{array}$ & Accounting \\
\hline
\end{tabular}

